\title{
Ultra-Performance Liquid Chromatographic Method for Simultaneous Quantification of HIV Non-Nucleoside Reverse Transcriptase Inhibitors and Protease Inhibitors in Human Plasma
}

\author{
Marina V. Antunes, ${ }^{a}$ Júlia Poeta, ${ }^{b}$ Jorge P. Ribeiro, ${ }^{b}$ Eduardo Sprinz ${ }^{b}$ and Rafael Linden $*, a$ \\ ${ }^{a}$ Instituto de Ciências da Saúde, Universidade Feevale, Rodovia RS 239 No. 2755, \\ 93352-000 Novo Hamburgo-RS, Brazil

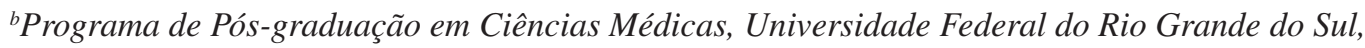 \\ Rua Ramiro Barcelos No. 2350, 90035-903 Porto Alegre-RS, Brazil
}

\begin{abstract}
Um método rápido para a determinação de seis inibidores de protease (indinavir, amprenavir, saquinavir, atazanavir, lopinavir e ritonavir) e de dois inibidores não-nucleosídicos da transcriptase reversa (efavirenz e nevirapine), empregando cromatografia líquida de ultra-eficiência com detector de arranjo de diodos foi desenvolvido e validado. Após extração liquido-líquido de 0,5 $\mathrm{mL}$ de plasma com metil-tert-butil éter, os analitos foram separados em uma coluna ACQUITY UPLC BEH ${ }^{\circledR} \mathrm{C} 18(2,1 \times 150 \mathrm{~mm}$, d.p. 1,7 $\mu \mathrm{m})$, eluída com um gradiente de tampão fosfato trietilamônio pH 3.0 e acetonitrila. O tempo total de análise cromatográfica foi de 9,5 min. As curvas de calibração foram lineares entre 0,1 a $10,0 \mu \mathrm{g} \mathrm{mL}^{-1}$. O limite inferior de quantificação foi $0,1 \mu \mathrm{g} \mathrm{mL} \mathrm{m}^{-1}$ para todos os fármacos. A exatidão esteve entre 94,9 e $103,5 \%$. Os coeficientes de variação intra e inter-dias foram inferiores a 7,7\% para todos os analitos. Os rendimentos de extração foram superiores a $88,2 \%$.
\end{abstract}

A fast ultra-performance liquid chromatographic with diode-array detection method has been developed and validated for the determination of six protease inhibitors (indinavir, amprenavir, saquinavir, atazanavir, lopinavir, and ritonavir) and two non-nucleoside reverse transcriptase inhibitors (efavirenz and nevirapine). After liquid-liquid extraction of $0.5 \mathrm{~mL}$ plasma with methyl-tert-butyl ether, the analytes were separated on a ACQUITY UPLC BEH ${ }^{\circledR} \mathrm{C} 18$ column $(2.1 \times 150 \mathrm{~mm}$, p.d. $1.7 \mu \mathrm{m})$ column eluted with a gradient of acetonitrile and triethylammonium phosphate buffer $5 \mathrm{mmol} \mathrm{L}^{-1} \mathrm{pH}$ 3.0. The total run time was $9.5 \mathrm{~min}$. Calibration curves were linear in the range 0.1 to to $10.0 \mu \mathrm{g} \mathrm{mL}^{-1}$. The lower limit of quantitation was $0.1 \mu \mathrm{g} \mathrm{mL} \mathrm{m}^{-1}$ for all drugs. Accuracy ranged from 94.9 to $103.5 \%$. Both interday and intraday coefficients of variation were less than $7.7 \%$ for all analytes. The extraction yields were greater than $88.2 \%$.

Keywords: antiretroviral drugs, ultra-performance liquid chromatography, therapeutic drug monitoring, UPLC-DAD

\section{Introduction}

Antiretroviral therapy for human immunodeficiency virus (HIV) infections usually consists of combinations of nucleoside reverse transcriptase inhibitors (NRTIs), non-nucleoside reverse transcriptase inhibitors (NNRTIs), protease inhibitors (PIs) and, more recently, entry inhibitors and integrase inhibitors. ${ }^{1}$ The currently approach to the therapy of HIV infection is the so-called "highly active antiretroviral therapy" (HAART), which is based on the combination of several drugs in the daily dosing

*e-mail: rafael.linden@ feevale.br regimen. The usual HAART scheme consists of one or more NRTIs, one or more PIs and one NNRTI. ${ }^{2}$ Several reports had demonstrated the relationship between plasma drug concentrations and clinical effects, either toxicity or efficacy, for compounds of the NNRTI and PI groups. ${ }^{3-8}$ Therefore, these drugs are prone for therapeutic drug monitoring (TDM) programs and, considering the necessity of interlaboratory comparison of results for the use of consensual therapeutic target levels, reliable analytical methods must be employed at their measurements.

Several HPLC methods have been published describing the simultaneous quantification of anti-HIV drugs in human biosamples. Most of these methods use $\mathrm{UV}^{9-15}$ 
or mass spectrometric detection. ${ }^{16-19}$ Protocols using spectrophotometric detectors are free from the matrix ionization effects observed in mass spectrometry and can also provide specific spectral information trough diode array detectors. Besides this advantages, the need of complete chromatographic separation of all compounds been measured usually determines long analytical runs, leading to low throughput and high consumption of solvents, and by consequence a considerably production of chemical waste. An alternative to conventional HPLC methods is ultra-performance liquid chromatography (UPLC) that could render faster and highly resolutive separations, keeping the advantages and robustness of UV detection modes, as has been described by Elens et al. ${ }^{20}$ for the measurement of anti-HIV drugs. In the present work we describe a novel validated UPLC assay, with the use of a photodiode array detector, for the measurement of the following anti-HIV drugs in human plasma: nevirapine, indinavir, amprenavir, saquinavir, atazanavir, ritonavir, efavirenz and lopinavir.

\section{Experimental}

\section{Chemicals}

Amprenavir, atazanavir sulfate, efavirenz, indinavir sulfate, lopinavir, nevirapine, ritonavir and saquinavir were kindly donated by the National Institutes of Health (NIH) AIDS Research and Reference Reagent Program (Germantown, USA). Clomipramine chloridrate was obtained from Purifarma Química e Farmacêutica (São Paulo, Brazil). Triethylammonium phosphate buffer $1 \mathrm{~mol} \mathrm{~L}^{-1} \mathrm{pH} 3.0$ was purchased from Fluka (Buchs, Switzerland). Tris(hydroxymethyl)aminomethane was purchased from Nuclear (Diadema, Brazil). Methanol, acetonitrile and methyl-tert-butyl ether (MTBE) were obtained from Merck (Darmstadt, Germany). Ultrapure water was obtained by an Elga Purelab Ultra apparatus from Elga Labwater (High Wycombe, UK).

\section{Preparation of solutions and standards}

Individual stock methanolic solutions of amprenavir, atazanavir sulfate, efavirenz, indinavir sulfate, lopinavir, nevirapine, ritonavir, saquinavir, and clomipramine chloridrate (internal standard) were prepared to obtain $1 \mathrm{mg} \mathrm{mL} \mathrm{m}^{-1}$ concentration of compound at base form. Working solutions were prepared combining aliquots of each stock solution and proper volumes of methanol to obtain solutions containing 1.0, 1.5, 2.0, 10.0, 20.0, 25.0, $50.0,80.0$ and $100.0 \mu \mathrm{g} \mathrm{mL}^{-1}$ of each analyte. The working solution of internal standard (IS) was prepared by dilution of stock with methanol to obtain a $50 \mu \mathrm{g} \mathrm{mL}^{-1}$ concentration. Mobile phase A was prepared daily diluting $500 \mu \mathrm{L}$ of Triethylammonium phosphate buffer $1 \mathrm{~mol} \mathrm{~L}^{-1}$ to $100 \mathrm{~mL}$ with ultrapure water to obtain a $5 \mathrm{mmol} \mathrm{L}^{-1}$ concentration, followed by filtration with $0.2 \mu \mathrm{m}$ cellulose acetate membranes from Sartorius (Göettingen, Germany). The $\mathrm{pH}$ of mobile phase A was adjusted to 3.0. Both mobile phases were sonicated for $15 \mathrm{~min}$ before use. Tris buffer $\mathrm{pH} 10.0$ was prepared dissolving $2.43 \mathrm{~g}$ of Tris(hydroxymethyl) aminomethane em $100 \mathrm{~mL}$ of ultrapure water, and the $\mathrm{pH}$ was properly adjusted.

\section{Equipment and chromatographic conditions}

The UPLC system consisted of an ACQUITY UPLC ${ }^{\circledR}$ coupled to an ACQUITY UPLC ${ }^{\circledR}$ photodiode array detector, both from Waters (Milford, USA). The separation was performed on an ACQUITY UPLC BEH ${ }^{\circledR} \mathrm{C} 18$ column $(2.1 \times 150 \mathrm{~mm}$, particle diameter of $1.7 \mu \mathrm{m})$. The system was controlled and data was managed by Empower 2 software, also from Waters. Mobile phase A was triethylammonium phosphate $5 \mathrm{mmol} \mathrm{L}^{-1}$ and mobile phase B was acetonitrile. At time zero, a mixture of $65 \%$ mobile phase A and $35 \%$ mobile phase $\mathrm{B}$ was pumped through the column at a

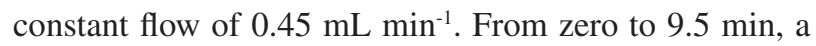
linear gradient was set to reach $43 \%$ of $\mathrm{A}$ and $57 \%$ of $\mathrm{B}$. The initial conditions were restored with a 0.1 min linear gradient, and then maintained for $0.9 \mathrm{~min}$. The total run time was $10.5 \mathrm{~min}$. The column temperature was set at $55^{\circ} \mathrm{C}$. Spectra were acquired for all peaks in the range of 205 to $380 \mathrm{~nm}$. Lopinavir was monitored at $215 \mathrm{~nm}$; saquinavir, efavirenz, ritonavir and IS were monitored at $240 \mathrm{~nm}$; indinavir and amprenavir were monitored at $260 \mathrm{~nm}$; and nevirapine and atazanavir were monitored at $280 \mathrm{~nm}$.

\section{Sample preparation}

To $2 \mathrm{~mL}$ disposable polypropylene tubes were added $500 \mu \mathrm{L}$ of either calibration, quality control or patient's plasma samples, $50 \mu \mathrm{L}$ of working internal standard solution, $100 \mu \mathrm{L}$ of Tris buffer $\mathrm{pH} 10.0$ and $1,000 \mu \mathrm{L}$ of methyl-tert-butyl ether. The tubes were capped and vortex mixed for $30 \mathrm{~s}$ and then centrifuged at $10,000 \mathrm{~g}$ for $10 \mathrm{~min}$ at $4{ }^{\circ} \mathrm{C}$. An aliquot of $900 \mu \mathrm{L}$ of the organic layer was evaporated to dryness at $50{ }^{\circ} \mathrm{C}$, under a gentle stream of air. The dried extract was recovered with $150 \mu \mathrm{L}$ of the initial mobile phase, vortex mixed for $30 \mathrm{~s}$ and centrifuged at $10,000 \mathrm{~g}$ for $10 \mathrm{~min}$ at $4{ }^{\circ} \mathrm{C}$. The supernatant was transferred for a autosampler vial and $10 \mu \mathrm{L}$ were injected into the UPLC system. 


\section{Selectivity}

Blank plasma samples from 6 different sources were prepared as described above to check for peaks that might interfere with the detection of the analytes or the IS. Blank plasma samples enriched with other antiretroviral drugs (abacavir, AZT, DDI, emtricitabine, lamivudine and nelfinavir; $1.0 \mu \mathrm{g} \mathrm{mL}^{-1}$ each) were also checked for interfering peaks.

\section{Stability}

For estimation of stability of processed samples under the conditions of analysis, control samples at 0.15 and $8.0 \mu \mathrm{g} \mathrm{mL} \mathrm{m}^{-1}(\mathrm{n}=5$ each $)$ were extracted as described above. The extracts obtained at each concentration were pooled. Aliquots of these pooled extracts at each concentration were transferred to autosampler vials and injected under the conditions of a regular analytical run at time intervals of $1 \mathrm{~h}$, during $12 \mathrm{~h}$. Stability of the analytes was tested by regression analysis plotting absolute peak areas corresponding to each compound at each concentration $v s$. injection time. Using the obtained linear regression, the concentration after $12 \mathrm{~h}$ was calculated. A decrease or increase of up to $10 \%$ in the measured peak areas was considered as acceptable. For evaluation of freeze-thaw stability, quality control samples at the same levels as in the benchtop stability experiment were analyzed before (control samples, $\mathrm{n}=3$ ) and after 3 freeze-thaw cycles (stability samples, $\mathrm{n}=9$ ). For each freeze-thaw cycle, the samples were frozen at $-20{ }^{\circ} \mathrm{C}$ for $48 \mathrm{~h}$, thawed, and kept at ambient temperature for $3 \mathrm{~h}$ before extraction. The concentrations of the control and stability samples were calculated from daily calibration curves. For the ratio of the stability sample means $v s$. the corresponding control sample means, an acceptance interval of 90-110\% was applied.

\section{Linearity}

Aliquots of blank plasma ( $450 \mu \mathrm{L})$ were enriched with $50 \mu \mathrm{L}$ of the corresponding working solutions to obtain calibration samples containing $0.1,0.2,1.0,2.5,5.0$, or $10.0 \mu \mathrm{g} \mathrm{mL} \mathrm{m}^{-1}$ of each analyte. Replicates $(\mathrm{n}=6)$ at each concentration were analyzed as described above. Calibration curves were constructed by calculating the ratios of the peak area of each compound to the peak area of the internal standard and comparing these ratios with the nominal concentrations of the calibration samples. Homoscedasticity of calibration data was evaluated with F-test at the confidence level of $95 \%$. Curves were fitted by least-squares linear regression using several weighting factor $\left(1 / \mathrm{x}, 1 / \mathrm{x}^{0.5}, 1 / \mathrm{x}^{2}\right.$, $\left.1 / \mathrm{y}, 1 / \mathrm{y}^{0.5}, 1 / \mathrm{y}^{2}\right)$. The calibration models were evaluated by their correlation coefficients (r) and cumulative percentage relative error ( $\left.\sum \% \mathrm{RE}\right)$ according to Almeida et al. ${ }^{21}$ Daily calibration curves using the same concentrations (single measurements per concentration) were prepared with each batch of validation and authentic samples.

\section{Accuracy and precision}

Aliquots of blank plasma $(450 \mu \mathrm{L})$ were enriched with $50 \mu \mathrm{L}$ of the corresponding working solutions to obtain quality control samples containing all analytes at 0.15 , 2.0 and $8.0 \mu \mathrm{g} \mathrm{mL}^{-1}$ (QCL, QCM and QCH, respectively). The quality control samples were analyzed as described above in triplicate on each of 5 days. The concentrations of all analytes in the quality control samples were calculated from daily calibration curves. Within-assay precision and between-day precision were calculated by one-way ANOVA with the grouping variable "day" and were expressed as CV\%. Accuracy was defined as the percentage of the nominal concentration represented by the concentration estimated with the calibration curve. The acceptance criterion for accuracy was mean values within $\pm 15 \%$ of the theoretical value and for precision was a maximum $\mathrm{CV}$ of $15 \% .{ }^{22}$

\section{Lower limit of quantification}

The lowest point of the calibration curves was $0.1 \mu \mathrm{g} \mathrm{mL}{ }^{-1}$ for all analytes. An independent quality control sample at this concentration was included in the accuracy and precision experiments (QCLLOQ) and was tested in triplicate in three different days. The acceptance criteria established for the limit of quantification was accuracy within $100 \pm 20 \%$ of the nominal value of the QC samples and a maximum $\mathrm{CV}$ of $20 \% .^{22}$

\section{Extraction efficiency}

The extraction efficiency was determined by comparing the peak areas of the analytes obtained at the plasma QC samples of the accuracy and precision experiments to those obtained with methanolic solutions at the same levels, measured in triplicate at three different days, in the same analytical batch. Extraction efficiency was expressed as percentage of the concentration of the reference samples.

\section{Method application}

The developed method was applied to 74 plasma samples from patients under anti-HIV therapy from the 
infectology service of a Brazilian tertiary hospital, after approval by institution's Ethics Research Committee. Trough blood samples were collected by venipuncture to EDTA containing tubes. After collection, the tubes were centrifuged within $30 \mathrm{~min}$ and plasma was separated. Plasma samples were kept at $-70{ }^{\circ} \mathrm{C}$ until analysis.

\section{Results and Discussion}

\section{Chromatography and sample preparation}

Most HPLC-UV methods for TDM of anti-HIV drugs have long run times, reducing their applicability for routine analysis, along with higher cost associated to the usage of solvents and the disposal of the chemical residues. In this study we described the fastest LC-UV method published for the measurement of the most important anti-HIV drugs currently monitored in HAART. Retention times for nevirapine, indinavir, saquinavir, amprenavir, atazanavir, efavirenz, ritonavir and lopinavir were 1.313, $1.781,3.631,3.884,6.261,7.338,7.883$ and $8.230 \mathrm{~min}$, respectively (Figure 1). The retention time of the internal standard was $2.996 \mathrm{~min}$. The total run time was $9.5 \mathrm{~min}$, shorter than the 14 min described by Elens et al. ${ }^{20}$ in the only previously published UPLC assay for anti-HIV drugs. The longer chromatographic analysis of Elens et $a l .{ }^{20}$ included the measurement of the late eluting protease inhibitor tipranavir, which was not present in our assay because this drug is not registered in Brazil, being excluded of the recommended therapeutic schemes of the Brazilian Ministry of Health. ${ }^{23,24}$ However, the retention times of Elens et al. ${ }^{20}$ were higher for all drug common for both assays: 4.844 for nevirapine, 8.033 for indinavir, 9.479 for amprenavir, 9.506 for saquinavir, 10.287 for atazanavir, 10.502 for efavirenz, 10.880 for lopinavir and 10.887 for ritonavir, with only partial resolution of these two analytes. Moreover, these authors employed an internal standard not commercially available, what reduces the practical application of the method. Total consumption of mobile phase in our assay was only $4.73 \mathrm{~mL}$ per analysis, far below from other published LC-UV methods, which could reach up to $67.5 \mathrm{~mL} .{ }^{15}$
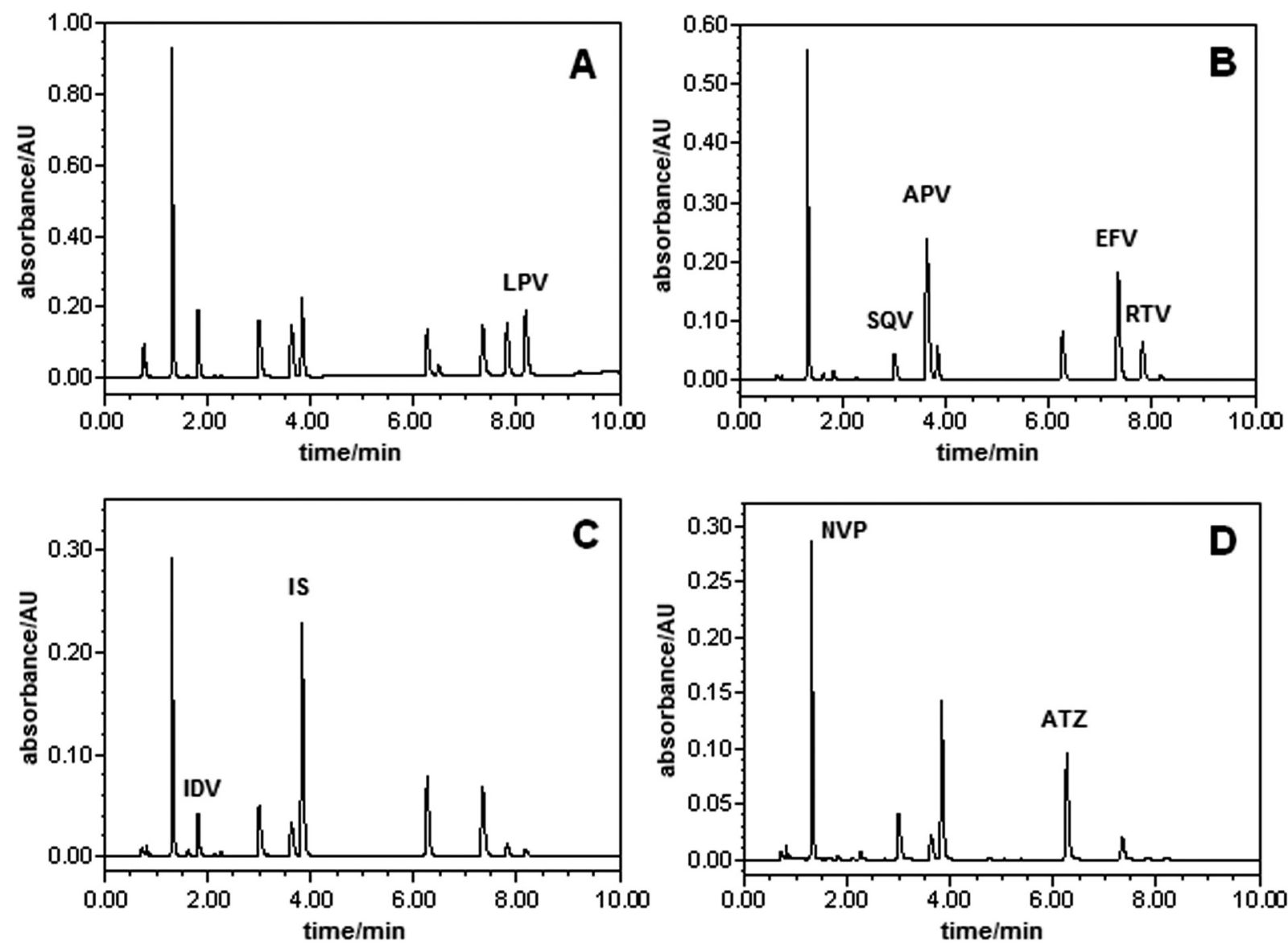

Figure 1. Chromatograms of blank plasma spiked with all drugs at $5 \mu \mathrm{g} \mathrm{mL} \mathrm{L}^{-1}$ and internal standard. A: measurement at $215 \mathrm{~nm}$; B: measurement at $240 \mathrm{~nm}$; C: measurement at $260 \mathrm{~nm}$; D: measurement at $280 \mathrm{~nm}$. Peak identification: $\mathrm{NVP}=$ nevirapine; IS = internal standard; IDV = indinavir; $\mathrm{SQV}=\mathrm{saquinavir}$; $\mathrm{APV}=$ amprenavir; $\mathrm{ATZ}=$ atazanavir; $\mathrm{EFV}=$ efavirenz; $\mathrm{RTV}=$ ritonavir $\mathrm{LPV}=$ lopinavir. 
Interfering endogenous plasma peaks were not observed in the blank samples (Figure 2). Retention times of abacavir, AZT, DDI, emtricitabine, lamivudine and nelfinavir were $0.816,0.932,0.812,0.667,0.752$ and $3.804 \mathrm{~min}$, respectively, presenting no inference with the measured drugs. Additionally, all analyte's peaks were evaluated with respect to their spectral purity and compared with library reference spectra, using the Empower ${ }^{\circledR}$ software. No spectral impurity was observed in identified peaks in any patient's tested sample.

In the present work, for means of simplicity and cost, we choose a liquid-liquid extraction procedure with MTBE to extract the drugs from plasma. This is the first description of the use of liquid-liquid extraction to the measurement of ARV drugs in plasma by UPLC. The extraction procedure was simple and inexpensive, with consistent yields in the range of 88.2 to $101.3 \%$ (Table 3), higher than previously described by solid-phase extraction. ${ }^{20}$

\section{Method validation}

There was no indication of instability of the analytes in any of the tested conditions (Table 1). Regression analysis of absolute peak areas of the analytes plotted $v s$. injection time indicated no instability of processed samples during a time interval of $12 \mathrm{~h}$, with concentration changes based on liner regression on the range of -3.8 to $6.8 \%$. The time frame of $12 \mathrm{~h}$ was determined considering the maximum run time needed for analysis of one batch of 50 samples with the developed method, including the sample preparation. The ratios of means (stability vs. control samples) of the freeze-thaw samples also fulfilled the acceptance criteria, with QC concentrations after three cycles on the range of 94.8 to $105.8 \%$ of control samples.
Calibration samples were prepared at six concentrations ranging from 0.1 to $10 \mu \mathrm{g} \mathrm{L}^{-1}$ for each analyte, covering concentrations that are to be expected for most authentic
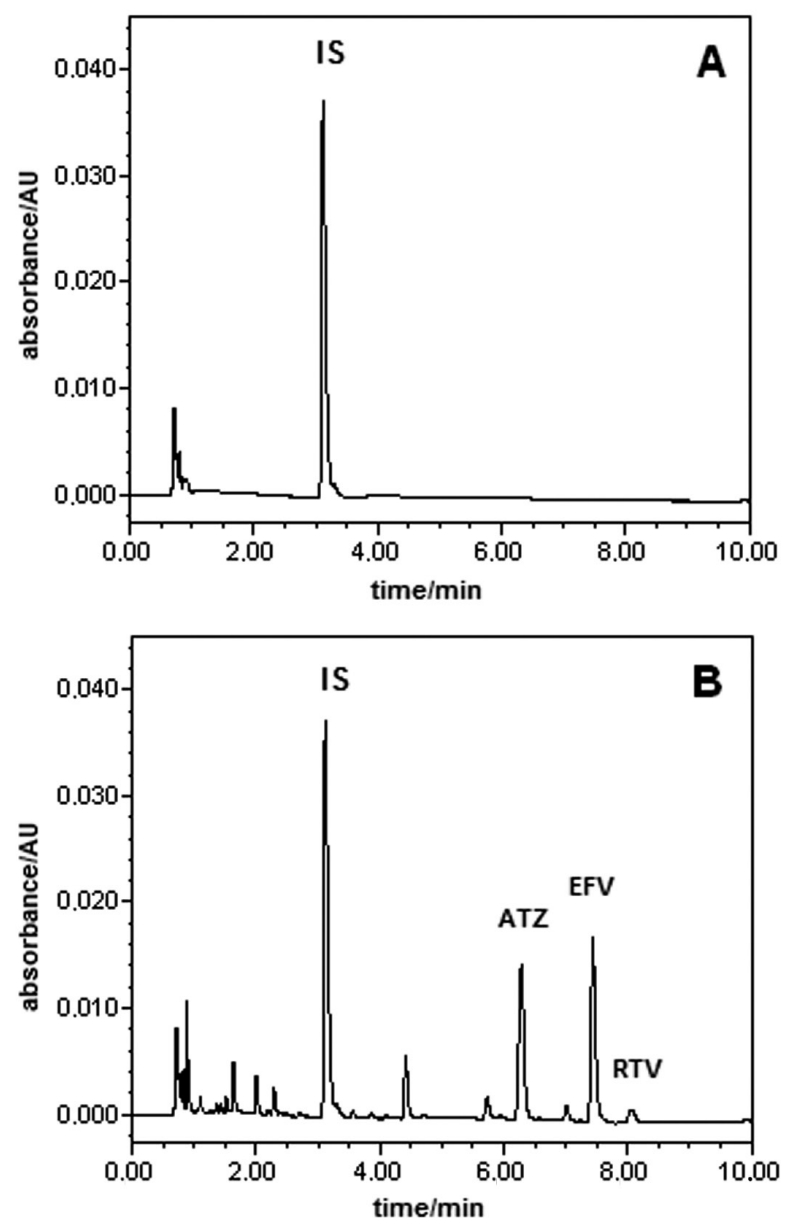

Figure 2. A: Blank plasma spiked with internal standard. B: Patient sample with internal standard (IS); atazanavir (ATZ, $1.61 \mu \mathrm{g} \mathrm{mL}^{-1}$ ); efavirenz (EFV, $1.88 \mu \mathrm{g} \mathrm{mL}^{-1}$ ) and ritonavir (RTV, $0.11 \mu \mathrm{g} \mathrm{mL}^{-1}$ ). Both chromatograms were monitored at $240 \mathrm{~nm}$.

Table 1. Benchtop stability and freeze and thaw stability

\begin{tabular}{|c|c|c|c|c|c|c|c|c|}
\hline \multirow{4}{*}{ Analyte } & \multicolumn{2}{|c|}{ Benchtop stability } & \multicolumn{6}{|c|}{ Freeze and thaw stability } \\
\hline & \multirow{2}{*}{\multicolumn{2}{|c|}{$\begin{array}{l}\text { Concentration change after } 12 \mathrm{~h} \\
\text { (based on regression) } /(\%)\end{array}$}} & \multicolumn{6}{|c|}{ Percentage of control concentration after each cycle* } \\
\hline & & & \multicolumn{2}{|c|}{ First } & \multicolumn{2}{|c|}{ Second } & \multicolumn{2}{|c|}{ Third } \\
\hline & $0.15 \mu \mathrm{g} \mathrm{mL}^{-1}$ & $8.0 \mu \mathrm{g} \mathrm{mL}^{-1}$ & $0.15 \mu \mathrm{g} \mathrm{mL}{ }^{-1}$ & $8.0 \mu \mathrm{g} \mathrm{mL}^{-1}$ & $0.15 \mu \mathrm{g} \mathrm{mL}-1$ & $8.0 \mu \mathrm{g} \mathrm{mL}^{-1}$ & $0.15 \mu \mathrm{g} \mathrm{mL}-1$ & $8.0 \mu \mathrm{g} \mathrm{mL} L^{-1}$ \\
\hline Nevirapine & 4.8 & 5.5 & 103.9 & 102.9 & 103.1 & 98.6 & 105.8 & 104.1 \\
\hline Indinavir & 5.9 & 4.9 & 101.5 & 97.9 & 105.8 & 99.4 & 102.5 & 103.8 \\
\hline Saquinavir & 6.8 & 2.3 & 99.8 & 95.5 & 99.4 & 101.8 & 98.7 & 102.3 \\
\hline Amprenavir & 4.5 & 3.6 & 106.4 & 105.1 & 96.7 & 94.1 & 103.8 & 100.7 \\
\hline Atazanavir & 0.9 & 2.5 & 94.7 & 96.8 & 105.4 & 103.7 & 102.8 & 97.3 \\
\hline Efavirenz & 2.5 & 3.9 & 98.7 & 95.8 & 101.6 & 101.4 & 101.5 & 104.4 \\
\hline Ritonavir & -3.8 & 4.9 & 93.5 & 94.2 & 100.7 & 107.1 & 96.4 & 96.7 \\
\hline Lopinavir & -3.2 & 3.9 & 105.4 & 99.4 & 93.7 & 94.8 & 97.1 & 102.7 \\
\hline
\end{tabular}

*compared to an aliquot of quality control samples analyzed before freezing. 
samples. The slopes (b) and $y$-intercepts (a), including 95\% confidence intervals of both variables, as well as the coefficients of correlation (r) and cumulative percentage relative error ( $\left.\sum \% \mathrm{RE}\right)$ for each analyte, as obtained in the linearity experiments, are listed in Table S1 (Supplementary Information). Several weighted regression models were evaluated in order to account to the significant heteroscedasticity of the calibration data. The best weighting factor was chosen according to the $\sum \% \mathrm{RE}$, defined as the sum of absolute percentage relative error (\%RE), which compares the regressed concentration computed from the regression equation obtained for each weighting factor, with the nominal standard concentration.
The inverse of the squared concentration $\left(1 / \mathrm{x}^{2}\right)$ was selected as the best weighting factor, with a maximum $\sum \% \mathrm{RE}$ of 0.1210 , contrasting to a maximum $\sum \% \mathrm{RE}$ of 847.89 when unweighted regression was applied. The coefficients of correlation were from 0.9920 to 0.999 . The back-calculated concentrations of all calibration samples fulfilled the criteria established by Shah et al. ${ }^{22}$

QC samples for accuracy and precision experiments were prepared at 3 concentrations (QCL, QCM, and $\mathrm{CQH}$ ) covering the calibration range. The results of the accuracy and precision experiments are given in Table 2. All accuracy values fulfilled the acceptance criteria for this parameter, lying within the range 94.9 to $103.5 \%$ of the nominal

Table 2. Precision, accuracy and extraction yield*

\begin{tabular}{|c|c|c|c|c|c|c|}
\hline \multirow{2}{*}{ Analyte } & \multirow{2}{*}{$\begin{array}{l}\text { QC sample / } \\
\left(\mu \mathrm{g} \mathrm{mL} \mathrm{mL}^{-1}\right)\end{array}$} & \multirow{2}{*}{$\begin{array}{c}\text { Nominal } \\
\text { concentration / } \\
\left(\mu \mathrm{gL}^{-1}\right)\end{array}$} & \multicolumn{2}{|c|}{ Precision / (CV\%) } & \multirow{2}{*}{$\begin{array}{c}\text { Accuracy / } \\
(\%)\end{array}$} & \multirow{2}{*}{$\begin{array}{c}\text { Extraction yield } \\
(\%)\end{array}$} \\
\hline & & & Within-assay & Between-assay & & \\
\hline \multirow[t]{4}{*}{ Nevirapine } & QCLLOQ & 0.1 & 10.5 & 9.8 & 108.5 & - \\
\hline & QCL & 0.15 & 7.2 & 6.9 & 101.2 & 90.2 \\
\hline & QCM & 2.0 & 4.9 & 3.5 & 95.6 & 89.3 \\
\hline & QCH & 8.0 & 4.7 & 2.8 & 99.7 & 88.2 \\
\hline \multirow[t]{4}{*}{ Indinavir } & QCLLOQ & 0.1 & 7.5 & 5.1 & 103.5 & - \\
\hline & QCL & 0.15 & 9.8 & 12.4 & 101.6 & 91.8 \\
\hline & QCM & 2.0 & 6.3 & 6.1 & 96.2 & 94.7 \\
\hline & $\mathrm{QCH}$ & 8.0 & 7.3 & 4.5 & 105.4 & 96.9 \\
\hline \multirow[t]{4}{*}{ Saquinavir } & QCLLOQ & 0.1 & 7.5 & 5.5 & 98.4 & - \\
\hline & QCL & 0.15 & 6.9 & 4.5 & 95.9 & 95.2 \\
\hline & QCM & 2.0 & 7.7 & 6.6 & 95.8 & 97.5 \\
\hline & QCH & 8.0 & 4.2 & 4.6 & 100.5 & 96.1 \\
\hline \multirow[t]{4}{*}{ Amprenavir } & QCLLOQ & 0.1 & 12.2 & 11.5 & 104.1 & - \\
\hline & QCL & 0.15 & 7.5 & 5.1 & 103.5 & 101.3 \\
\hline & QCM & 2.0 & 5.2 & 4.6 & 95.8 & 98.6 \\
\hline & QCH & 8.0 & 4.3 & 3.4 & 101.7 & 99.8 \\
\hline \multirow[t]{4}{*}{ Atazanavir } & QCLLOQ & 0.1 & 8.2 & 7.8 & 98.7 & - \\
\hline & QCL & 0.15 & 5.9 & 3.6 & 95.8 & 97.1 \\
\hline & QCM & 2.0 & 6.5 & 4.5 & 95.4 & 101.1 \\
\hline & $\mathrm{QCH}$ & 8.0 & 3.9 & 3.4 & 99.3 & 97.3 \\
\hline \multirow[t]{4}{*}{ Efavirenz } & QCLLOQ & 0.1 & 7.8 & 5.8 & 103.5 & - \\
\hline & QCL & 0.15 & 7.3 & 4.3 & 102.7 & 89.2 \\
\hline & QCM & 2.0 & 6.7 & 5.7 & 102.4 & 91.5 \\
\hline & QCH & 8.0 & 5.3 & 6.7 & 104.4 & 93.8 \\
\hline \multirow[t]{4}{*}{ Ritonavir } & QCLLOQ & 0.1 & 7.4 & 7.7 & 107.2 & - \\
\hline & QCL & 0.15 & 4.3 & 6.2 & 98.8 & 91.7 \\
\hline & QCM & 2.0 & 6.5 & 7.3 & 102.7 & 94.5 \\
\hline & $\mathrm{QCH}$ & 8.0 & 6.4 & 5.4 & 104.8 & 90.7 \\
\hline \multirow[t]{4}{*}{ Lopinavir } & QCLLOQ & 0.1 & 9.8 & 13.5 & 92.8 & - \\
\hline & QCL & 0.15 & 6.8 & 7.1 & 98.7 & 88.9 \\
\hline & QCM & 2.0 & 6.4 & 4.8 & 94.9 & 92.1 \\
\hline & $\mathrm{QCH}$ & 8.0 & 4.4 & 4.4 & 97.4 & 88.2 \\
\hline
\end{tabular}

$*(\mathrm{n}=15$ for QCL, QCM and QCH; $\mathrm{n}=9$ for QCLLOQ). 
concentrations. With-assay assay precision was in the range of 3.9 to $7.7 \%$, where between-assay precision was 3.4 to $7.3 \%$, also being accepted.

Another QC sample containing the analytes at concentrations equal to those of the lowest point of the calibration curve (QCLLOQ) was prepared to determine whether the criteria for analytical recovery and precision were fulfilled even at these concentrations, which corresponded to the practical LLOQ. The QCLLOQ presented accuracy in the range of 92.8 to 108.5 , withinassay precision of 6.5 to $12.2 \%$, and between-assay of 4.4 to $13.5 \%$, fulfilling the acceptance criteria for the lower limit of quantification.

\section{Method application}

In 91 single drug measurements, we found 15 values outside the target ranges for treatment-naive patients previously published..$^{25}$ These outlier values were obtained for efavirenz (range 0.077 to $13.38 \mu \mathrm{g} \mathrm{mL}^{-1}, 11$ from 40 measurements outside the target range) and lopinavir (range 0.168 to $11.51 \mu \mathrm{g} \mathrm{mL}^{-1}, 3$ from 11 measurements outside the target range). As expected, there is a wide variation on the plasma concentration of the measured anti-HIV drugs, even when standardized posology is employed, what corroborates the use of TDM in these patients. Moreover, considering the reported relation of plasma concentration of NNRTI and PI to virological response, the significant interindividual pharmacokinetic variation, the numerous potential drug interactions and the possibility to check for compliance, TDM represents an invaluable tool to optimize anti-HIV drug therapy. ${ }^{26}$

\section{Conclusions}

A fast gradient UPLC-PDA method for the simultaneous determination of nevirapine, indinavir, amprenavir, saquinavir, atazanavir, efavirenz, lopinavir and ritonavir in $500 \mu \mathrm{L}$ of human plasma samples was described. The total run time was $9.5 \mathrm{~min}$, with consumption of only $4.73 \mathrm{~mL}$ of mobile phase for each analysis. When compared to usual HPLC methods, the developed method was faster and demanded significantly smaller amounts of mobile phase. The sample preparation was based on a simple liquid-liquid extraction with MTBE. This is the first report of the determination of antiretroviral drugs in biosamples using liquid-liquid extraction associated to UPLC-DAD. The method showed to be precise, accurate and specific and was applied to 74 patient's samples, were 15 of 91 single measurements were outside published therapeutic ranges.

\section{Supplementary Information}

Supplementary data are available free of charge at http://jbcs.sbq.org.br, as PDF file.

\section{Acknowledgments}

The authors are grateful to the National Institutes of Health (NIH) AIDS Research and Reference Reagent Program (Germantown, USA) for the kind donation of reference samples of anti-HIV drugs and to the Universidade Feevale, for the financial support.

\section{References}

1. http://www.fda.gov/oashi/aids/virals.html, acessed in January 2010.

2. Oxenius, A.; Price, D. A.; Easterbrook, P. A.; O’Callaghan, C. A.; Kelleher, A. D.; Whelan, J. A.; Sontag, G.; Sewell, A. K.; Phillips, R. E.; Proc. Natl. Acad. Sci. 2000, 97, 3382.

3. Wateba, M. I.; Billaud, E.; Dailly, E.; Jolliet, P.; Raffi, F.; HIV Med. 2006, 7, 197.

4. Gutierrez, F.; Padilla, S.; Navarro, A.; Masiá, M.; Hernández, I.; Ramos, J.; Estéban, A.; Martin-Hidalgo, A.; J. Acquir. Immune Defic. Syndr. 2003, 33, 594.

5. Seminari, E.; Gentilini, G.; Galli, L.; Hasson, H.; Danise, A.; Carini, E.; Dorigatti, F.; Soldarini, A.; Lazzarin, A.; Castagna, A.; J. Antimicrob. Chemother. 2005, 56, 790.

6. van Leth, F. V.; Kappelhoff, B. S.; Johnson, D.; Losso, M. H.; Boron-Kaczmarska, A.; Saag, M. S.; Livrozet, J-M.; Hall, D. B.; Leith, J.; Huitema, A. D. R.; Wit, F. W.; Beijnen, J. H.; Lange, J. M. A.; AIDS Res. Hum. Retroviruses 2006, 22, 232.

7. Kappelhoff, B. S.; van Leth, F.; Robinson, P. A.; MacGregor, T. R.; Baraldi, E.; Montella, F.; Uip, D. E.; Thompson, M. A.; Russel, D. B.; Lange, J. M.; Beijnen, J. H.; Huitema, A. D.; Antivir. Ther. 2005, 10, 489.

8. Back, D.; Gibbons S.; Khoo, S.; Ther. Drug Monit. 2006, 28, 468.

9. Takahashi, M.; Yoshida, M.; Oki, T.; Okumura, N.; Suzuki, T.; Kaneda, T.; Biol. Pharm. Bull. 2005, 28, 1286.

10. Poirier, J. M.; Robidou, P.; Jaillon, P.; Ther. Drug Monit. 2005, 27, 186.

11. Rezk, N. L.; Crutchley, R. D.; Yeh, R. F.; Kashuba, A. D. M.; Ther. Drug Monit. 2006, 28, 517.

12. Colombo, S.; Béguin, A.; Marzolini, C.; Telenti, A.; Biollaz, J.; Decosterd, L. A.; J. Chromatogr., B: Anal. Technol. Biomed. Life Sci. 2006, 832, 138.

13. Weller, D. R.; Brundage, R. C.; Balfour, H. H; Vezina, H. E.; J. Chromatogr., B: Anal. Technol. Biomed. Life Sci. 2007, 848, 369. 
14. Dailly, E.; Reliquet, V.; Victorri-Vigneau, C.; Raffi, F.; Jolliet, P.; J. Chromatogr., B: Anal. Technol. Biomed. Life Sci. 2006, $832,317$.

15. Titier, K.; Lagrange, F.; Péhourcq, F.; Edno-Mcheik, L.; Moore, N.; Molimard, M.; Ther. Drug Monit. 2002, 24, 417.

16. Dickinson, L.; Robinson, L.; Tjia, J.; Khoo, S.; Back, D.; J. Chromatogr., B: Anal. Technol. Biomed. Life Sci. 2005, $829,82$.

17. Rebiere, H.; Mazel, B.; Civade, C.; Bonnet, P. A.; J. Chromatogr., B: Anal. Technol. Biomed. Life Sci. 2007, 850,376

18. D’Avolio, A.; Siccardi, M.; Sciandra, M.; Lorena, B.; Bonora, S.; Trentini, L.; Di Perri, G.; J. Chromatogr., B: Anal. Technol. Biomed. Life Sci. 2007, 859, 234.

19. Gehrig, A. K.; Mikus, G.; Haefeli, W. E.; Burhenne, J.; Rapid Commun. Mass Spectrom. 2007, 21, 2704.

20. Elens, L.; Veriter, S.; Di Fazio, V.; Vanbinst, R.; Boesmans, D.; Wallemacq, P.; Haufroid, V.; Clin. Chem. 2009, 55, 170.

21. Almeida, A. M.; Castel-Branco, M. M.; Falcão, A. C.; $J$. Chromatogr., B: Anal. Technol. Biomed. Life Sci. 2002, 774, 215.
22. Shah, V. P.; Midha, K. K., Findlay, J. W. A.; Hill, H. M.; Hulse, J. D.; McGilveray, I. J.; McKay, G.; Miller, K. J.; Patnaik, R. N.; Powell, M. L.; Tonelli, A.; Viswanathan, C. T.; Yacobi, A.; Pharm. Res. 2000, 17, 1551.

23. Brazilian Ministry of Health; Recommendations on Antiretroviral Therapy in HIV-Infected Children and Adolescents. Brasília, 2009. Available at http://www.aids.gov.br/sites/default/files/ consenso_pediatrico.pdf. Acessed in August 2010.

24. Brazilian Ministry of Health; Recommendations on Antiretroviral Therapy in HIV-Infected Adults. Brasília, 2008. Available at http://www.aids.gov.br/sites/default/files/ consensoAdulto005c_2008montado.pdfAcessed in August 2010.

25. la Porte, C. J. L.; Back, D. J.; Blaschke, T.; Boucher, C. A. B.; Fletcher, C. V.; Flexner, C.; Gerber, J. G.; Kashuba, A. D. M.; Shapiro, J.; Burger, D. M.; Rev. Antivir. Ther. 2006, 3, 4.

26. van Luin, M.; Kuks, P. F. M.; Burger, D. M.; Curr. Opin. HIV AIDS 2008, 3, 266. 


\title{
Ultra-Performance Liquid Chromatographic Method for Simultaneous Quantification of HIV Non-Nucleoside Reverse Transcriptase Inhibitors and Protease Inhibitors in Human Plasma
}

\author{
Marina V. Antunes, ${ }^{a}$ Júlia Poeta, ${ }^{b}$ Jorge P. Ribeiro, ${ }^{b}$ Eduardo Sprinz ${ }^{b}$ and Rafael Linden $*, a$ \\ Instituto de Ciências da Saúde, Universidade Feevale, Rodovia RS 239 No. 2755, \\ 93352-000 Novo Hamburgo-RS, Brazil \\ ${ }^{\text {b} P r o g r a m a ~ d e ~ P o ́ s-g r a d u a c ̧ a ̃ o ~ e m ~ C i e ̂ n c i a s ~ M e ́ d i c a s, ~ U n i v e r s i d a d e ~ F e d e r a l ~ d o ~ R i o ~ G r a n d e ~ d o ~ S u l, ~}$ \\ Rua Ramiro Barcelos No. 2350, 90035-903 Porto Alegre-RS, Brazil
}

Table S1. Summary of the evaluation of the calibration models

\begin{tabular}{|c|c|c|c|c|c|c|c|c|c|}
\hline \multirow[t]{2}{*}{ Weighting factor } & \multirow{2}{*}{$\begin{array}{l}\text { Regression } \\
\text { parameters } \\
( \pm 95 \% \mathrm{CI})\end{array}$} & \multicolumn{8}{|c|}{ Analyte } \\
\hline & & Nevirapine & Indinavir & Saquinavir & Amprenavir & Atazanavir & Efavirenz & Ritonavir & Lopinavir \\
\hline \multirow[t]{4}{*}{ unweighted } & $b$ & $0.2801( \pm 0.0018)$ & $0.0590( \pm 0.0058)$ & $0.5362( \pm 0.0058)$ & $0.3958( \pm 0.0045)$ & $0.1945( \pm 0.0019)$ & $0.3964( \pm 0.0026)$ & $0.1424( \pm 0.0043)$ & $0.3921( \pm 0.0027)$ \\
\hline & $a$ & $-0.0046( \pm 0.0034)$ & $-0.0032( \pm 0.0117)$ & $-0.0360( \pm 0.0111)$ & $-0.0232( \pm 0.0086)$ & $-0.0069( \pm 0.0036)$ & $-0.0171( \pm 0.0051)$ & $-0.0084( \pm 0.0083)$ & $-0.0045( \pm 0.0053)$ \\
\hline & $r$ & 0.9999 & 0.9993 & 0.9982 & 0.9994 & 0.9990 & 0.9970 & 0.9996 & 0.9998 \\
\hline & $\sum \% \mathrm{RE}$ & 282.08 & 847.89 & 689.77 & 749.57 & 308.97 & 468.13 & 602.93 & 526.48 \\
\hline \multirow[t]{4}{*}{$1 / x$} & $b$ & $0.2772( \pm 0.0022)$ & $0.0573( \pm 0.0077)$ & $0.5229( \pm 0.0077)$ & $0.3852( \pm 0.0061)$ & $0.1924( \pm 0.0024)$ & $0.3898( \pm 0.0036)$ & $0.1393( \pm 0.0055)$ & $0.3883( \pm 0.0039)$ \\
\hline & $a$ & $+0.0043( \pm 0.0043)$ & $+0.0024( \pm 0.0148)$ & $+0.0057( \pm 0.0148)$ & $+0.0102( \pm 0.0116)$ & $-0.0001( \pm 0.0048)$ & $+0.0039( \pm 0.0071)$ & $+0.0013( \pm 0.0105)$ & $+0.0118( \pm 0.0074)$ \\
\hline & $r$ & 0.9999 & 0.9990 & 0.9993 & 0.9992 & 0.9998 & 0.9996 & 0.9995 & 0.9997 \\
\hline & $\sum \% \mathrm{RE}$ & $-9.73 \times 10^{-13}$ & 0.5812 & -0.0112 & -0.1373 & -0.0870 & -0.0777 & -0.0404 & 180.73 \\
\hline \multirow[t]{4}{*}{$1 / \mathrm{x}^{0.5}$} & $b$ & $0.2785( \pm 0.0019)$ & $0.0581( \pm 0.0065)$ & $0.5291( \pm 0.0065)$ & $0.3900( \pm 0.0051)$ & $0.1934( \pm 0.0021)$ & $0.3930( \pm 0.0029)$ & $0.1407( \pm 0.0047)$ & $0.3846( \pm 0.0031)$ \\
\hline & $a$ & $+0.0022( \pm 0.0037)$ & $+0.0009( \pm 0.0125)$ & $-0.0055( \pm 0.0124)$ & $+0.0018( \pm 0.0097)$ & $-0.0021( \pm 0.0039)$ & $-0.0021( \pm 0.0057)$ & $-0.0012( \pm 0.0091)$ & $+0.0119( \pm 0.0059)$ \\
\hline & $r$ & 0.9999 & 0.9992 & 0.9995 & 0.9993 & 0.9999 & 0.9998 & 0.9995 & 0.9994 \\
\hline & $\sum \% \mathrm{RE}$ & 60.453 & 198.18 & 169.70 & 172.67 & 80.032 & 123.22 & 140.02 & 146.40 \\
\hline \multirow[t]{4}{*}{$1 / x^{2}$} & $b$ & $0.2753( \pm 0.0028)$ & $0.0551( \pm 0.0137)$ & $0.5033( \pm 0.0137)$ & $0.3751( \pm 0.0122)$ & $0.1880( \pm 0.0061)$ & $0.3764( \pm 0.0095)$ & $0.1353( \pm 0.0097)$ & $0.3661( \pm 0.0126)$ \\
\hline & $a$ & $+0.0050( \pm 0.0054)$ & $+0.0031( \pm 0.0263)$ & $+0.0127( \pm 0.0264)$ & $+0.0138( \pm 0.0235)$ & $+0.0014( \pm 0.0115)$ & $+0.0087( \pm 0.0183)$ & $+0.0027( \pm 0.0185)$ & $+0.0255( \pm 0.0242)$ \\
\hline & $r$ & 0.9999 & 0.9980 & 0.9975 & 0.9991 & 0.9987 & 0.9970 & 0.9986 & 0.9920 \\
\hline & $\sum \% \mathrm{RE}$ & $-7.69 \times 10^{-13}$ & -0.1124 & 0.0223 & -0.1201 & 0.1056 & -0.0055 & -0.2544 & 0.1210 \\
\hline \multirow[t]{4}{*}{$1 / y$} & $b$ & $0.2772( \pm 0.0022)$ & $0.0572( \pm 0.0077)$ & $0.5226( \pm 0.0077)$ & $0.3848( \pm 0.0061)$ & $0.1924( \pm 0.0024)$ & $0.3898( \pm 0.0036)$ & $0.1393( \pm 0.0055)$ & $0.3852( \pm 0.0037)$ \\
\hline & $a$ & $+0.0043( \pm 0.0043)$ & $+0.0022( \pm 0.0149)$ & $+0.0045( \pm 0.0149)$ & $+0.0009( \pm 0.0117)$ & $-0.0003( \pm 0.0046)$ & $+0.0029( \pm 0.0069)$ & $+0.0011( \pm 0.0106)$ & $+0.0160( \pm 0.0071)$ \\
\hline & $r$ & 0.9999 & 0.9990 & 0.9993 & 0.9991 & 0.9998 & 0.9997 & 0.9995 & 0.9995 \\
\hline & $\sum \% \mathrm{RE}$ & 2.7721 & 37.493 & 24.403 & 22.223 & 8.7711 & 23.953 & 14.721 & 68.802 \\
\hline \multirow[t]{4}{*}{$1 / \mathrm{y}^{0.5}$} & $b$ & $0.2784( \pm 0.0019)$ & $0.0581( \pm 0.0065)$ & $0.5291( \pm 0.0065)$ & $0.3900( \pm 0.0051)$ & $0.1934( \pm 0.0021)$ & $0.3930( \pm 0.0029)$ & $0.1407( \pm 0.0047)$ & $0.3886( \pm 0.0031)$ \\
\hline & $a$ & $+0.0021( \pm 0.0037)$ & $+0.0007( \pm 0.0124)$ & $-0.0066( \pm 0.0124)$ & $+0.0006( \pm 0.0097)$ & $-0.0021( \pm 0.0039)$ & $-0.0028( \pm 0.0056)$ & $-0.0014( \pm 0.0091)$ & $+0.0099( \pm 0.0058)$ \\
\hline & $r$ & 0.9999 & 0.9992 & 0.9995 & 0.9993 & 0.9999 & 0.9998 & 0.9995 & 0.9997 \\
\hline & $\sum \% \mathrm{RE}$ & 65.752 & 244.04 & 190.79 & 206.62 & 84.691 & 139.56 & 153.37 & 193.47 \\
\hline \multirow[t]{4}{*}{$1 / y^{2}$} & $b$ & $0.2751( \pm 0.0029)$ & $0.0552( \pm 0.0134)$ & $0.5035( \pm 0.0133)$ & $0.3742( \pm 0.0122)$ & $0.1879( \pm 0.0061)$ & $0.3770( \pm 0.0093)$ & $0.1354( \pm 0.0096)$ & $0.3709( \pm 0.0099)$ \\
\hline & $a$ & $+0.0051( \pm 0.0056)$ & $+0.0030( \pm 0.0256)$ & $+0.0115( \pm 0.0256)$ & $+0.0138( \pm 0.0233)$ & $+0.0012( \pm 0.0117)$ & $+0.0076( \pm 0.0178)$ & $+0.0025( \pm 0.0184)$ & $+0.0212( \pm 0.0191)$ \\
\hline & $r$ & 0.9999 & 0.9984 & 0.9977 & 0.9991 & 0.9986 & 0.9972 & 0.9987 & 0.9943 \\
\hline & $\sum \% \mathrm{RE}$ & 1.2901 & 18.121 & 22.193 & 8.6132 & 12.693 & 21.683 & 12.273 & 68.224 \\
\hline $\begin{array}{l}\text { Test of } \\
\text { homoscedasticity }\end{array}$ & $F_{\text {exp }}$ & $1,376.49$ & $1,405.79$ & $1,454.06$ & 779.97 & $1,821.94$ & $1,089.13$ & $1,199.08$ & $1,895.21$ \\
\hline
\end{tabular}

$\mathrm{F}_{\text {tab }}(5.5 .0 .95)=5.05$.

*e-mail: rafael.linden@feevale.br 